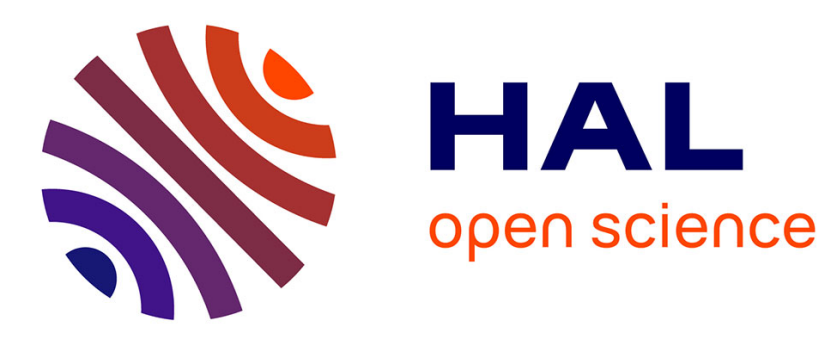

\title{
Condition-dependent clutch desertion in Great Tit () females subjected to human disturbance
}

Anna Dubiec

\section{To cite this version:}

Anna Dubiec. Condition-dependent clutch desertion in Great Tit () females subjected to human disturbance. Journal für Ornithologie = Journal of Ornithology, 2011, 152 (3), pp.743-749. 10.1007/s10336011-0647-8 . hal-00664191

\section{HAL Id: hal-00664191 https://hal.science/hal-00664191}

Submitted on 30 Jan 2012

HAL is a multi-disciplinary open access archive for the deposit and dissemination of scientific research documents, whether they are published or not. The documents may come from teaching and research institutions in France or abroad, or from public or private research centers.
L'archive ouverte pluridisciplinaire HAL, est destinée au dépôt et à la diffusion de documents scientifiques de niveau recherche, publiés ou non, émanant des établissements d'enseignement et de recherche français ou étrangers, des laboratoires publics ou privés. 
Anna Dubiec

Institute of Environmental Sciences, Jagiellonian University

Gronostajowa 7, 30-387 Kraków, Poland

Current address: Museum and Institute of Zoology, Polish Academy of Sciences Wilcza 64, 00-679 Warszawa

e-mail: adubiec@ miiz.waw.pl 
1 Abstract

2 Nest desertion behaviour in relation to body condition and timing of breeding was studied in

3 Great Tit (Parus major) females during two breeding seasons. Desertion, most likely

4 unintentionally provoked by catching females during the incubation period, occurred at a very

5 high rate with $41.2 \%$ and $25.6 \%$ of deserted first clutches in the two study years. The

6 association between desertion probability, body condition (index calculated as residuals from

7 the regression of body mass on tarsus length) and timing of breeding differed between the

8 seasons with the highest probability of desertion among females in low condition laying early

9 in the season in one year and females in low condition laying late in the season in the other

year. Desertion probability was best predicted by body condition with females in low

condition deserting at much higher rate than females in good condition. These results suggest that nest desertion by females subjected to disturbance during the early stage of the nesting cycle may be associated with the level of their body reserves and that patterns of desertion in relation to body condition and timing of breeding may differ between years.

Key words: body condition; laying date; nest desertion; incubation; Parus major

\section{Zusammenfassung}

Verlassen des Geleges nach Störung durch Menschen bei weiblichen Kohlmeisen (Parus major) in Abhängigkeit von ihrer körperlichen Verfassung

Während zweier Brutperioden wurde bei weiblichen Kohlmeisen das Verlassen der Gelege im Zusammenhang mit ihrer körperlichen Verfassung und dem Zeitpunkt des Brütens untersucht. Das Verlassen, höchstwahrscheinlich unabsichtlich vom Fang der Weibchen während des Brütens ausgelöst, trat in den beiden Untersuchungsjahren mit hoher Rate auf: 41,2\% und 25,6\% Erstgelege wurden verlassen. Der Zusammenhang zwischen Verlassens-

\footnotetext{
Wahrscheinlichkeit, körperlicher Verfassung (Index berechnet als Residuen einer Regression
} 
1 von Körpermasse und Tarsus-Länge) und Zeitpunkt des Brütens variierte zwischen den

2 Jahreszeiten; die höchste Verlassens-Wahrscheinlichkeit gab es bei Weibchen in weniger

3 guter Verfassung und früher Brutzeit in dem einen Jahr und Weibchen in nicht guter

4 Verfassung und später Brutzeit in dem anderen Jahr. Die körperliche Verfassung als Prädiktor

5 der Verlassens-Wahrscheinlichkeit stimmte am besten für Weibchen in nicht guter

6 Verfassung, bei denen die Verlassens-Rate viel höher lag als bei Weibchen in gutem

7 physischen Zustand. Diese Ergebnisse legen die Annahme nahe, dass das Verlassen der

8 Gelege von im frühen Niststadium gestörten Weibchen mit dem Stand ihrer Körperreserven

9 zusammenhängt und das Verlassen in Abhängigkeit von der körperlichen Verfassung und der

10 Zeit des Brütens von Jahr zu Jahr unterschiedlich sein könnte.

11

12

13

14

15

16

17

18 
1 According to life history theory parental decisions regarding the investment in reproduction

2 are based on the trade-off between the value of the current and future breeding attempts

3 (Sargent and Gross 1985, Stearns 1992). Specifically, the current investment is expected to be

4 shaped on one hand by future reproductive benefits and on the other hand by past investments

5 to the extent these investments influence the ability of the individual to invest in reproduction

6 in the future (Montgomerie and Weatherhead 1988, Coleman and Gross 1991, Gross 2005). If

7 for example fitness costs associated with caring for a current breeding attempt outweigh the

8 benefits, the parents may reduce the level of parental investment including its complete

9 termination (Székely et al. 1996).

One of the most important factors which may influence the reproductive decisions at the proximate level, is the state of the organism (McNamara and Houston 1996), most commonly measured as body condition. This parameter has been shown to affect such important components of reproductive performance as decisions regarding the initiation of breeding in a given season and whether to abandon an already initiated attempt (e.g. Newton et al. 1983;

Chastel et al. 1995). The latter component has been especially well recognized in seabirds, in which desertion of the breeding attempt at the stage of clutch incubation is often associated with a critical body mass, i.e. the mass when the metabolism starts to be fueled by proteins instead of lipids (Olsson 1997; Ancel et al. 1998).

Body condition may affect the magnitude of parental investment including its termination as a sole factor or alternatively it may act in combination with other factors, such as the time within the season or the age of the offspring (Székely et al. 1996; Webb et al. 2002). The optimization model developed by Webb et al. (2002) predicts that when offspring are very young parents should desert the nest if they are in such a short of energy reserves that they face the death of starvation. However, this effect is expected to be observed only at the beginning of the breeding season. As breeding season advances young offspring should be 
1 deserted at progressively higher reserve levels. However, in case of older young, the parental

2 body condition should not affect their propensity for desertion irrespective of the time within

3 the season.

4 In birds desertion may occur at each stage of the nesting cycle: nest building, egg laying,

5 incubation and offspring rearing. Depending on the nesting stage and the mode of parental

6 care may cause from very large to relatively small fitness consequences. If, in a species with a

7 biparental care, desertion occurs at the stage which requires the contribution of a specific

8 parent, usually a female (e.g. nest building or incubation), desertion by this parent is

9 equivalent to a complete termination of that breeding attempt. If, on the other hand, desertion occurs at the stage, at which the presence of only one parent, either male of female, may be sufficient to successfully bring the offspring to independence, desertion by one of the parents may only decrease to some extent the fitness benefits from that breeding attempt (Székely et al. 1996).

The aim of this study was to investigate whether desertion is associated with body condition and timing of breeding in a small short-living passerine, the great tit (Parus major).

16 Desertion decisions should exert especially distinct fitness consequences in such species because of their very limited breeding opportunities. In the great tit the majority of birds survive to reproduce only during one breeding season (Payevsky 2006). In the current study desertion was unintentionally provoked by human disturbance involving catching and blood sampling during the incubation period. The data was collected as part of two other studies

21 focusing on seasonal patterns of reproductive success and immune function activity in the great tit (Dubiec et al. 2005, Dubiec and Cichoń 2005). Because in this species only females incubate, their desertion at this stage is equivalent to a nest failure. Although nest desertion was induced by human disturbance, it may be interpreted as an adaptive response to the perceived risk of predation (Székely et al. 1996). Based on the model of Webb et al. (2002) it 
1 was predicted that body condition and laying date interact to affect the propensity for

2 desertion in response to human disturbance: as season progresses, the body condition

3 threshold for deserting females would increase. Given that body condition and laying date

4 affect the desertion probability independently of each other it was predicted that: 1) birds in

5 worse condition are either more (because of low expected reproductive value of the clutch) or

6 less (because of very limited future breeding opportunities in this species) prone to desert the

7 clutch and 2) the probability of clutch desertion decreases with the advancement of the

8 season because the chances of laying and successful rearing of the replacement clutch late in

9 the season are constrained by food availability and time (Bauchau and Seinen 1997;

10 Fernandez and Reboreda 2000) or alternatively 3) the probability of clutch desertion increases

11 with the advancement of the season because the value of the offspring, measured as e.g. body

12 mass and immune function, declines with the progress of the season (Dubiec and Cichon

13 2005; Rossmanith et al. 2007).

14

$15 \quad$ Methods

16 The study was conducted on a great tit population breeding in nest boxes (40 boxes/10 ha,

17 in total 240 boxes; the occupation rate by great tits was $24.6 \%$ in 2000 and $21.2 \%$ in 2001) in

18 a deciduous forest in southern Poland (Niepolomice Forest, $50^{\circ} 00^{\prime} \mathrm{N}, 20^{\circ} 15^{\prime} \mathrm{E}$ ) in 2000 and

19 2001. From the middle of April nest boxes were inspected every week to record the laying

20 date of the first egg. When more than one egg was found in the nest, the laying day was back-

21 calculated assuming that one egg was laid every day. The nests were next visited when the

22 clutch was assumed to be completed, i.e. on the 15th day after laying the first egg as great tit

23 females lay at the most 14 eggs in the study area (own data). If the female was in the nest box

24 she was gently chased out to count the eggs. Following this visit females were caught on the

25 nest by hand on the 12th day of incubation in 2000 and the 6th day of incubation in 2001 . 
1 Great tit females start incubation after completing the clutch and incubate on average for 13

2 days, so the 6th and 12th day refer to the middle and the end of the incubation period,

3 respectively (Gosler 1993). Females were ringed with a numbered aluminium ring, weighed

4 with a Pesola spring balance to the nearest $0.1 \mathrm{~g}$ and had tarsus length measured with a calliper

5 to the nearest $0.1 \mathrm{~mm}$. Additionally, in 2000 all females were sampled for blood for the

6 analyses of the leukocyte level as part of a study on seasonal variation in the leukocyte

7 concentration and reproductive output (Dubiec et al. 2005). The nests were checked again

8 around the expected hatching date. During this visit nests were classified as either attended or

9 deserted based on the presence of the female or the eggs' temperature. In all nests classified as

10 deserted the eggs were collected and then examined for the stage of embryo development.

11 Based on the results of examination it was concluded that desertion occurred most probably

12 shortly after the capture of females. Unoccupied nest boxes were visited till the end of June to record all breeding attempts. Clutches were classified as first, replacement or second ones based on the individual identification of females and the status of the earlier breeding attempt. Only the first clutches were used in the analyses of desertion behaviour.

The probability of clutch desertion was analysed with logistic regression using body condition, laying date, year and their interactions as explanatory variables (Sokal and Rohlf 1995). The stage of the incubation period was not introduced in the model, because female capture either in the middle or the end of incubation was used only in a single year and consequently, it may interact with year effects. Laying dates for each of the two years were

21 standardized by subtracting the date of clutch initiation from the mean laying date. Body 22 condition, which is used as an indicator of the energetic state of the organism, was calculated as the residuals from the regression of body mass on tarsus length separately for each season

24 (Schulte-Hostedde et al. 2005). A significant interaction between body condition and laying date was considered to confirm that body condition influences the probability of desertion in a 
1 time-dependent way. Twelve females nesting in 2000 also laid the clutch in 2001, therefore,

2 to meet the assumption of independent sampling, only one breeding attempt, either in 2000 or

3 2001, was selected randomly for the analyses. Three females breeding in 2000 were excluded

4 from the analyses because very late laying dates and small clutch sizes indicate that these

5 were most probably the second or replacement clutches of individuals, which laid first

6 clutches in natural holes. The sample size was further reduced by excluding three females,

7 which escaped before body mass was weighed and one which was weighed and measured at

8 the end of the nesting period. In total, 59 females in 2000 and 51 females in 2001 produced

9 first clutches, of which 51 and 43 were used in the analyses, respectively. Statistical tests were

10 considered significant at $\alpha=0.05$. The analyses were performed in Statistica ver. 7.1

11 (StatSoft, Inc.).

12

$13 \quad$ Results

14 Laying date and clutch size pronouncedly differed between the two breeding seasons. In 2000 females started laying a week earlier than in 2001 (Mann-Whitney $U$ test, mean \pm SD, day $1=1$ April, 2000: $19.9 \pm 2.6,2001: 26.8 \pm 4.5, z=-7.01, P<0.001)$ and they laid on average 1 egg more than females in 2001 ( $t$ test, mean \pm SD: 2000: $11.5 \pm 1.05,2001: 10.5 \pm$ $\left.1.25, \mathrm{t}_{95}=4.41, P<0.001\right)$.

In 2000, 21 (41.2\%) females deserted the nest after being caught, while in 2001, 11 (25.6\%) females showed such behaviour. The association between desertion behavior and

21 body condition and timing of breeding differed between two breeding seasons as indicated by a significant three-way interaction term (Table 1). In 2000 the highest probability of desertion was associated with low body condition and early laying dates, while in 2001 - with low body condition and late laying dates (Fig. 1). The analysis within each of the breeding seasons showed that the interaction between body condition and laying date did not affect the 
1 desertion probability of the clutch in 2000, while in 2001 there was a tendency for such an

2 interaction (2000: body condition: Wald $\chi^{2}=2.43$, $\mathrm{df}=1, P=0.111$, laying date: Wald $\chi^{2}=$

$30.90, \mathrm{df}=1, P=0.342$, body condition*laying date: Wald $\chi^{2}=1.14, \mathrm{df}=1, P=0.285 ; 2001$ :

4 body condition: Wald $\chi^{2}=4.77, \mathrm{df}=1, P=0.029$, laying date: Wald $\chi^{2}=2.23, \mathrm{df}=1, P=$

$5 \quad 0.135$, body condition*laying date: Wald $\left.\chi^{2}=2.74, \mathrm{df}=1, P=0.098\right)$.

6 Desertion of the clutch was strongly associated with female body condition with

7 individuals in low condition deserting at much higher rate than females in good condition

8 (Table 1, Fig. 1). Laying date was not associated with the propensity for desertion, although

9 the effect of this variable tended to differ between years. In 2000 the probability of desertion

tended to decrease as the season progressed (Wald $\chi^{2}=1.96, \mathrm{df}=1, P=0.161$ ), while in 2001

11 it tended to increase (Wald $\left.\chi^{2}=2.31, \mathrm{df}=1, P=0.129\right)$.

The majority of deserting females, namely $66.7 \%$ in 2000 and $72.7 \%$ in 2001 laid a replacement clutch, always in a new box.

Discussion

The very high desertion rates recorded in this study were most likely induced by handling birds and in 2000 additionally by blood sampling. Observations from the previous breeding seasons in the population under study indicate that birds not disturbed during incubation desert the nest only occasionally. Similar results on nest desertion in response to human disturbance have been shown in other great tit populations as well as other species. Kilgas et al. (2007) demonstrated the desertion rate of $37 \%$ in great tits, which were exposed to capture and blood sampling during incubation, while Kania (1989) found 29\% deserted nests in this species following the capture of females during incubation as compared to a desertion rate of $2 \%$ among undisturbed nests. Similarly, common eider (Somateria mollissima) females captured and bled during incubation were more likely to desert the nest 
1 than females exposed to human disturbance only in the form of flushing from the nest

2 (Criscuolo 2001). It has been suggested that birds view the capture by humans as a predation event (Silverin 1998), therefore their reproductive decisions following the capture may be interpreted as an adaptive response to the perceived risk of predation (Székely et al. 1996). This study presents a rather complex pattern of association between desertion behavior and 6 body condition and timing of breeding in great tit females during the incubation period. The 7 effects of body condition and laying date on the probability of female desertion differed between two study years. In 2000 the highest rate of desertion was among early laying females in low body condition, while in 2001 among late laying females in low body condition. Only in one of the seasons, 2001, body condition threshold for deserting females tended to increase as the season progressed as predicted by the model of Webb et al. (2002). In 2000 birds commenced first clutches exceptionally early for the study area (own data), and on average a week earlier than in 2001. This advancement inlaying dates may have changed the seasonal pattern of reproductive value of the brood as well as the prospects for future reproduction resulting in differences between years in determinants of desertion behaviour. According to life history theory natural selection favours behaviours which maximize lifetime reproductive success based on the trade-off between current and future reproduction (Williams 1966, Stearns 1992). If costs associated with continuing to care at any given moment of a reproductive cycle outweigh the benefits of such behavior, birds are expected to abandon a current breeding attempt. This may happen if the reproductive value of the clutch

21 decreases, which may be caused for example by a partial clutch loss or increase in predation risk (Cavalcanti 1981). In the light of this theory the increased probability of clutch desertion in response to human disturbance by females in poor body condition may be associated with the expected low reproductive quality, and consequently low fitness benefits, of their clutch. 
1 high-quality ones have been commonly documented (e.g. Drent and Daan 1980, Clutton-

2 Brock 1988). Consequently, given that in this species the majority of individuals, most

3 probably primarily low quality birds, have the opportunity to reproduce only during one

4 breeding season (Payevsky 2006), abandoning the clutch of low reproductive quality under

5 the increased risk of predation may be selected for if deserting individuals have high re-

6 nesting potential (even though replacement clutches are smaller and have lower fledging

7 success than the first clutches (own data)). In the study population $66.7 \%$ of females in 2000

8 and $72.7 \%$ in 2001 laid a replacement clutch, which indicates the existence of such potential.

9 All re-laying females commenced a replacement clutch in a new nest box. Such behaviour

10 seems to be adaptive, because predators commonly return to once depredated nests and

11 shifting to a new breeding site increases the chances of successful reproduction (e.g. Sonerud 12 1985).

13 One of the proximate mechanisms underlying the propensity for desertion in great tit

14 females in poor condition may involve physiological effects of corticosterone. The concentration of this glucocorticosteroid is negatively related to body condition (Kitaysky et al. 1999; Adams et al. 2005) and a high level may trigger behavioural responses such as an increase in foraging activities (Wingfield et al. 1997). The corticosterone level increases rapidly in response to capture and handling (e.g. Schwabl et al. 1991; Cockrem and Silverin 2002), therefore, if this hormone is already at high levels in those females that have a low condition score, the disturbance at the nest may cause the increase in the corticosterone level over some threshold, which may provoke the desertion behaviour.

The studies on desertion behavior in relation to body condition of incubating birds produced so far equivocal results. In seabirds, a group of birds in which both males and females take part in incubation in turns, and the individual involved in incubation fasts during this period, clutch desertion by parents in poor body conditions have been observed for 
1 example in blue petrels (Halobaena caerulea) and the Magellanic penguin (Spheniscus

2 magellanicus), but not in the common diving petrel (Pelecanoides urinatrix) and the thin-

3 billed prion (Pachyptila belcheri) (Ancel et al. 1998, Chastel et al. 1995, Yorio and Boersma

4 1994). In the collared flycatcher (Ficedula albicollis), a small passerine, females deserting the

5 nest were in lower body condition than those that successfully completed incubation (Wiggins

6 et al. 1994). However, the difference in body condition between deserters and non-deserters

7 was pronounced only under poor weather conditions. In great tits, Kilgas et al. (2007) found,

8 contrary to the present study, no difference in body condition between deserting and non-

9 deserting females, which were weighted and sampled for blood on the $5^{\text {th }}$ day after the clutch completion. Hõrak et al. (1999), on the other hand, showed that great tit females that hatched

11 young and subsequently deserted the brood at the second part of the nesting period were in

12 better condition (including nutritional condition) than non-deserters. However, given that nestling mortality shortly after hatching was much higher in subsequently deserted nests, high body condition of deserters may have been be associated with reduced provisioning needs.

Laying date did not affect the desertion probability in the population under study, although its effects tended to differ between the seasons: in 2000 there was a slight decrease in the probability of desertion as the season progressed, while in 2001 - a slight increase. Similarly, in a population of great tits, in which desertion was provoked in a subset of nests by an experimental clutch reduction on day 8 of incubation, the probability of desertion did not differ between early and late breeders (Verboven 1998). Either negative or positive association between laying date and the desertion probability is expected based on the assumption of a seasonal decline in re-laying opportunities and seasonal deterioration of the offspring quality (Bauchau and Seinen 1997; Fernandez and Reboreda 2000; Dubiec and Cichoń 2005; Rossmanith et al. 2007). Such association, in most cases with late-laid clutches being more often deserted than early-laid ones, have been found for example in the collared 
1 flycatcher, the fan-tailed warbler (Cisticola juncidis), the greater rhea (Rhea americana), the

2 sparrowhawk (Accipiter nisus) and the song sparrow (Melospiza melodia) (Cavalcanti 1981,

3 Newton and Marquiss 1984, Ueda 1987, Wiggins et al. 1994, Fernandez and Reboreda 2000).

4 The lack of this relation in the population under study may be explained by the fact that both

5 mechanisms operate in the population, but because of their opposite effects they cancel out

6 each other. Alternatively, the selection pressures may not be strong enough to produce sharp

7 increase or decrease in the desertion probability as the season progresses. The opposite effects

8 of laying date on the desertion probability in 2000 and 2001 indicate that year effects may be

9 an important factor in shaping desertion decisions in relation to time in the season in species

10 breeding in a seasonal environment.

11 In conclusion, this study indicates that the influence of body condition and laying dates on

12 desertion behavior in incubating birds may be influenced by year effects. Although the very

13 high desertion rates among great tit females were most likely promoted by human

14 disturbance, the findings of this study suggest that individuals in low and high body condition

15 respond differently to stressors during this stage of the nesting period and that this response

16 may be differently related to time within the season between breeding seasons.

Acknowledgements

I thank Magdalena Witek, Magdalena Stoczko and other students for help in the field. Geir A.

Sonerud, Raivo Mänd and Tomasz Mazgajski provided valuable comments on previous drafts

21 of the manuscript. The study was financially supported by grants from the State Committee

22 for Scientific Research of Poland (No. 6 P04C 079 19) and Jagiellonian University (No.

$23 \mathrm{BW} / \mathrm{V} / \mathrm{INoS} / 7 / 99)$. The study complies with the current laws of the Republic of Poland. 
1 Adams NJ, Cockrem JF, Taylor GA, Candy EJ, Bridges J (2005) Corticosterone responses of grey-faced petrels (Pterodroma macroptera gouldi) are higher during incubation than during other breeding stages. Physiol Biochem Zool 78:69-77

Ancel A, Fetter L, Groscolas R (1998) Changes in egg and body temperature indicate triggering of egg desertion at a body mass threshold in fasting incubating blue petrels (Halobaena caerulea). J Comp Physiol B 168:533-539

Bauchau V, Seinen I (1997) Clutch desertion and re-nesting in pied flycatchers: an experiment with progressive clutch removal. Anim Behav 54:153-161

Cavalcanti RB (1981) Nest desertion : theory and tests of its adaptive significance in birds.

Dissertation, McGill University

Chastel O, Weimerskirch H, Jouventin P (1995) Body condition and seabird reproductive performance: A study of three petrel species. Ecology 76:2240-2246

Clutton-Brock TH (1988) Reproductive success. University of Chicago Press, Chicago

Cockrem JF, Silverin B (2002) Variation within and between birds in corticosterone responses of great tits (Parus major). Gen Comp Endocr 125:197-206

Coleman RM, Gross MR (1991) Parental investment theory - the role of past investment. Trends Ecol Evol 6:404-406

Criscuolo F (2001) Does blood sampling during incubation induce nest desertion in the reproductive output in female great tits (Parus major). Auk 122:829-834

Dubiec A, Cichoń M (2005) Seasonal decline in nestling cellular immunocompetence results 
1 Fernandez GJ, Reboreda JC (2000) Egg losses and nest desertion in Greater Rheas Rhea americana. Ibis 142:29-34

3 Gosler A (1993) The Great Tit. Hamlyn Limited, London

4 Gross MR (2005) The evolution of parental care. Q Rev Biol 80:37-45

5 Hõrak P, Tegelmann L, Ots I, Møller AP (1999) Immune function and survival of great tit nestlings in relation to growth conditions. Oecologia 121:316-322

Kania W (1989) Brood desertion by great tits Parus major caught at the nest. Acta Ornithol 25:77-105

Kilgas P, Tilgar V, Mägi M, Mänd R (2007) Physiological condition of incubating and brood rearing female Great Tits Parus major in two contrasting habitats. Acta Ornithol 42: 129_ 136

Kitaysky AS, Wingfield JC, Piatt JF (1999) Dynamics of food availability, body condition and physiological stress response in breeding black-legged kittiwakes. Funct Ecol

McNamara JM, Houston AI (1996) State-dependent life histories. Nature 380:215-221

Montgomerie RD, Weatherhead PJ (1988) Risks and rewards of nest defence by parent birds. Q Rev Biology 63: 167-187.

Newton I, Marquiss M, Village A (1983) Weights, breeding, and survival in European sparrowhawks. Auk 100:344-354

Newton I, Marquiss M (1984) Seasonal trend in the breeding performance of sparrowhawks. J Anim Ecol 53:809-829

Olsson O (1997) Clutch abandonment: a state-dependent decision in king penguins. J Avian Biol 28:264-267

Payevsky VA (2006) Mortality rate and population density regulation in the great tit, Parus 
1 Rossmanith E, Hontsch K, Blaum N, Jeltsch F (2007) Reproductive success and nestling diet in the Lesser Spotted Woodpecker (Picoides minor): the early bird gets the caterpillar. J Ornithol 148:323-332

Sargent RC, Gross MR (1985) Parental investment decision rules and the Concorde fallacy. Behav Ecol Sociobiol 17:43-45

Schwabl H, Bairlein E, Gwinner E (1991) Basal and stress-induced corticosterone levels of garden warblers, Sylvia borin, during migration. J Comp Physiol B 161:576-580

Schulte-Hostedde AI, Zinner B, Millar JS, Hickling GJ (2005) Restitution of mass-size residuals: Validating body condition indices. Ecology 86:155-163

Silverin B (1998) Stress responses in birds. Poult Avian Biol Rev 9:153-168

Sokal RR, Rohlf FJ (1995) Biometry. Freeman, New York

Sonerud GA (1985) Nest hole shift in Tengmalm's owl Aegolius funereus as defence against nest predation involving long-term memory in the predator. J Anim Ecol 54:179-192

StatSoft, Inc. (2005). STATISTICA (data analysis software system), version 7.1. www.statsoft.com

Stearns SC (1992) The evolution of life histories. Oxford University Press, Oxford

Székely T, Webb JN, Houston AI, McNamara JM (1996) An evolutionary approach to offspring desertion in birds. Curr Ornithol 13:271-330

Ueda K (1987) Brood desertion in the fan-tailed warbler Cisticola juncidis. Jap J Ornith $36: 13-18$

Verboven N (1998) Multiple breeding in a seasonal environment. Dissertation, the Netherlands Institute of Ecology

Webb JN, Székely T, Houston AI, McNamara JM (2002) A theoretical analysis of the energetic costs and consequences of parental care decisions. Phil Trans R Soc Lond B $357: 331-340$ 
1 Wiggins DA, Pärt T, Gustafsson L (1994) Correlates of clutch desertion by female Collared Flycatchers Ficedula albicollis. J Avian Biol 25:93-97

3 Williams GC (1966) Natural selection, costs of reproductionand a refinement of Lack's principle. Am Nat 100:687-690

Wingfield JC, Bruener C, Jacobs J (1997) Corticosterone and behavioural responses to unpredictable events. In: Harvey S., Etches RJ (eds) Perspectives in Avian Endocrinology. Society for Endocrinology, Bristol, pp 267-278

Yorio P, Boersma PD (1994) Causes of nest desertion during incubation in the Magellanic penguin (Spheniscus magellanicus). Condor 96:1076-1083

23 Table 1. The probability of clutch desertion in great tit females in relation to year, body condition, laying date and their interactions during two breeding seasons. Explanatory variables were introduced in the model as a block. 


\begin{tabular}{lccccc}
\hline & B & SE & Wald & df & $P$ \\
\hline year & 0.52 & 0.29 & 3.23 & 1 & 0.072 \\
body condition & -0.98 & 0.37 & 7.14 & 1 & 0.008 \\
laying date & 0.15 & 0.29 & 0.27 & 1 & 0.604 \\
year*body condition & 0.44 & 0.37 & 1.45 & 1 & 0.229 \\
year*laying date & -0.52 & 0.29 & 3.07 & 1 & 0.080 \\
body condition*laying date & 0.26 & 0.34 & 0.58 & 1 & 0.446 \\
year*body condition*laying date & -0.68 & 0.34 & 3.88 & 1 & 0.049 \\
\hline
\end{tabular}

2

3

4

5

6

7

8

9

10

11

12

13

14

15

16

17

$18 \quad$ Figure captions

19 
1 Figure 1. The probability of clutch desertion in relation to body condition and laying date in

2 great tit females subjected to human disturbance in two study years (A:2000, B:2001).

3

4

5

6

7

8

9

10

11

12

13

14

15

16

17

18

19

20

21

22

23

$24 \quad$ Fig. 1.

25 A 


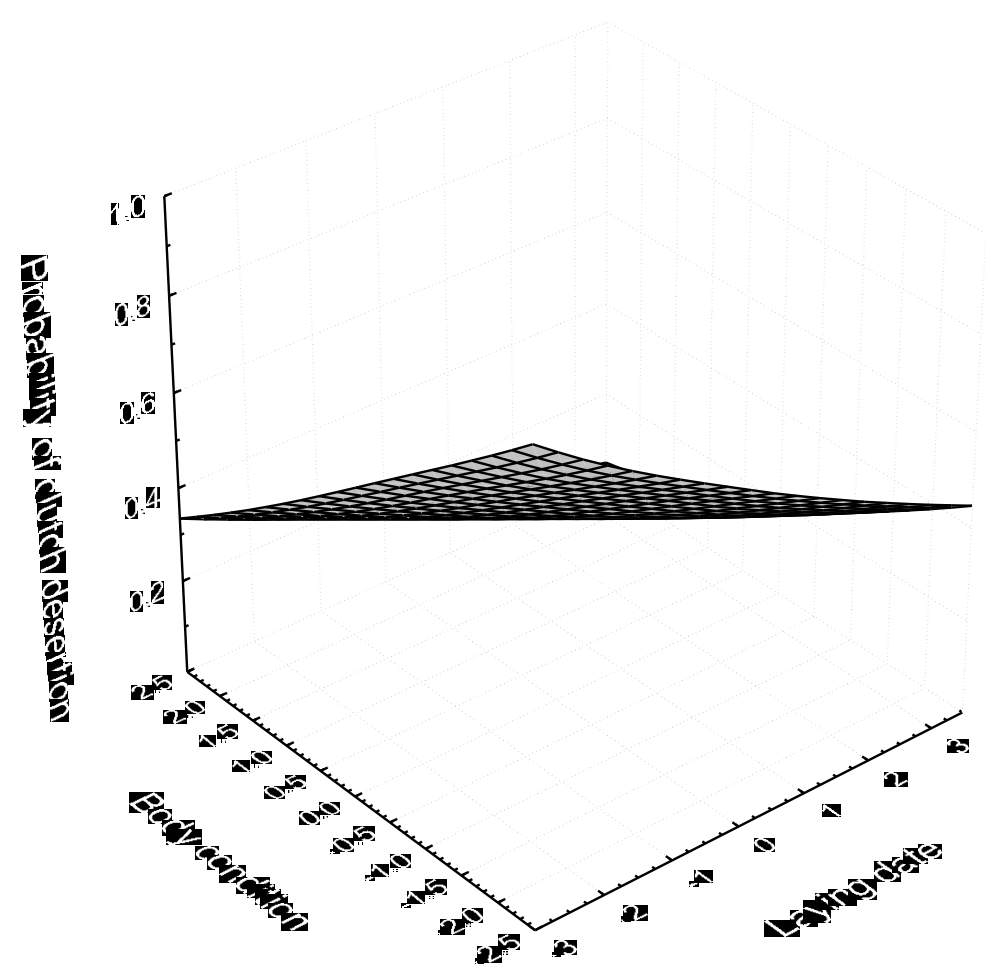

1

20 


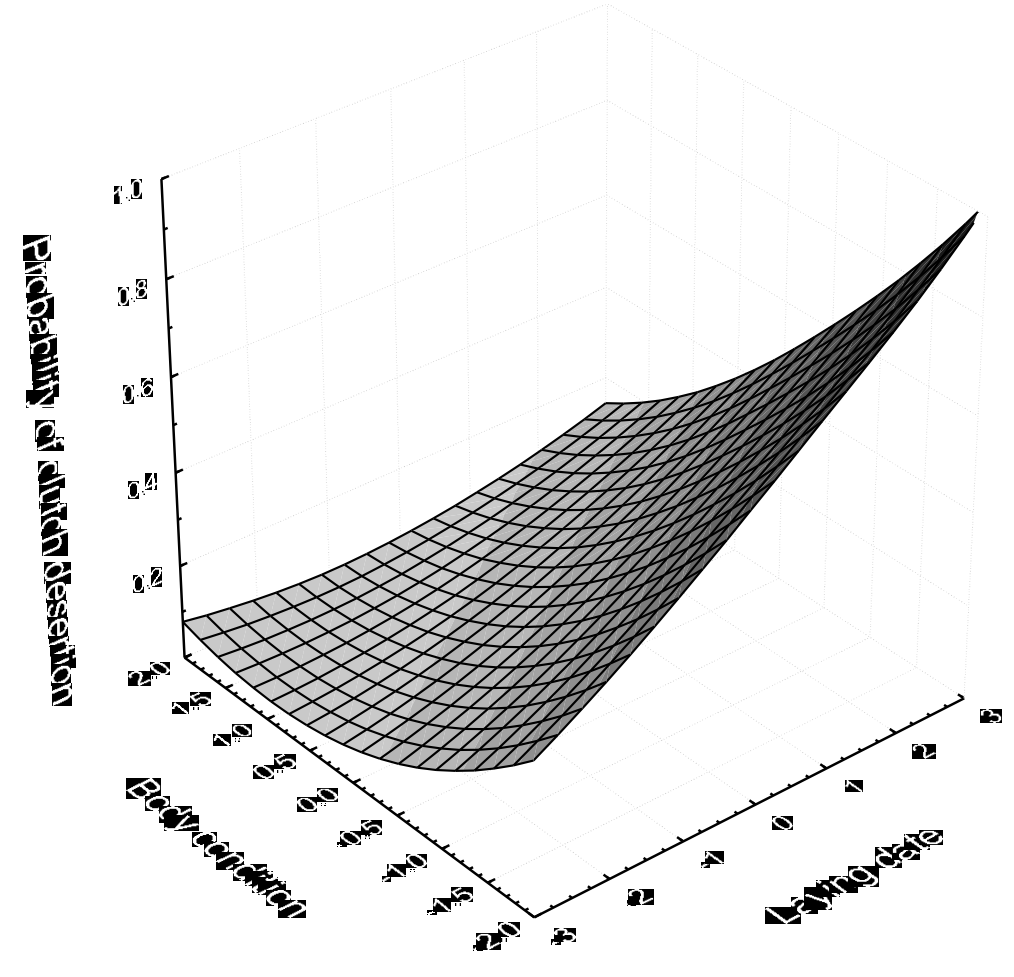

1 